\title{
Advancing antimicrobial stewardship: Summary of the 2015 CIDSC Report
}

\author{
Khan $\mathrm{F}^{1}$, Arthur $\mathrm{J}^{1 *}$, Maidment $\mathrm{L}^{1}$, Blue $\mathrm{D}^{2}$ on behalf of the 2015 Communicable and Infectious \\ Disease Steering Committee (CIDSC) Antimicrobial Use (AMU) Stewardship Task Group ${ }^{3}$
}

\section{Abstract}

Background: Antimicrobial resistance (AMR) is recognized as an important global public health concern that has a cross-cutting impact on human health, animal health, food and agriculture and the environment. The Communicable and Infectious Disease Steering Committee (CIDSC) of the Pan-Canadian Public Health Network (PHN) created a Task Group on Antimicrobial Stewardship to look at this issue from a Canadian perspective.

Objective: To summarize the key findings of the Task Group Report that identified core components of antimicrobial stewardship programs, best practices, key challenges, gaps and recommendations to advance stewardship across jurisdictions.

Methods: Search strategies were developed to identify scientific literature, grey literature and relevant websites on antimicrobial stewardship. The information was reviewed, and based on this evidence, expert opinion and consensus-building, the Task Group identified core components, best practices, key challenges and gaps and developed recommendations to advance stewardship in Canada.

Results: The four components of a promising antimicrobial stewardship initiative were: leadership, interventions, monitoring/evaluation and future research. Best practices include a multi-sectoral/multipronged approach involving a wide range of stakeholders at the national, provincial/territorial, local and health care organizational levels. Key challenges and gaps identified were: the success and sustainability of stewardship undertakings require appropriate and sustained resourcing and expertise; there is limited evidence about how to effectively implement treatment guidance; and there is a challenge in ensuring accessibility, standardization and consistency of use among professionals.

Recommendations to the CIDSC about how to advance stewardship across jurisdictions included the following: institute a national infrastructure; develop best practices to implement stewardship programs; develop education and promote awareness; establish consistent evidence-based guidance, resources, tools and training; mandate the incorporation of stewardship education; develop audit and feedback tools; establish benchmarks and performance targets for stewardship; and conduct timely evaluation of stewardship programs.

Conclusion: Findings of this report will inform a more systematic approach to addressing antimicrobial stewardship Canada-wide.

\author{
Affiliations \\ ${ }^{1}$ Centre for Communicable \\ Diseases and Infection Control, \\ Public Health Agency of Canada, \\ Ottawa, ON \\ ${ }^{2}$ Office of the Chief Medical \\ Officer of Health, Edmonton, $A B$ \\ ${ }^{3}$ See Acknowledgements section \\ for a full list of Task Group \\ members
}

*Correspondence: jacqueline. arthur@phac-aspc.gc.ca

Suggested citation: Khan F, Arthur J, Maidment L, Blue D on behalf of the 2015 Communicable and Infectious Disease Steering Committee (CIDSC) Antimicrobial Use (AMU) Stewardship Task Group. Advancing antimicrobial stewardship: Summary of the 2015 CIDSC Report. Can Comm Dis Rep. 2016;42(11):238-41.

\section{Introduction}

Antimicrobial resistance (AMR) is recognized as an increasingly significant global health issue that threatens the effective prevention, control and treatment of a wide spectrum of infections. In Canada, the emergence of antimicrobial resistant organisms has been identified as a major concern in health care settings and among at-risk populations. Since AMR may emerge in bacteria as a response to selective antimicrobial pressure (i.e., when bacteria is in the presence of an antimicrobial drug), there is a potential risk that fewer and fewer antimicrobials will remain effective in the future. Unnecessary antibiotic treatment has been shown to account for a substantial burden of inappropriate antimicrobial use in Canada (1-4). Due to growing concern about the link between antimicrobial usage (AMU) and AMR, a shift towards more prudent use of antimicrobials has been one of the areas emphasized in combatting the spread of AMR (5-8).

Antimicrobial stewardship is the responsible planning and management of resources in order to prevent and moderate the development of AMR. Antimicrobial stewardship initiatives and related programs typically address issues related to AMU in 
order to limit the spread of AMR and conserve the effectiveness of existing antimicrobials. Stewardship is applied in different settings and can also encompass activities outside the human health sector in a One Health model. The Report recognized that parallel action is needed in veterinary, food animal health and in the agriculture sectors; however, its focus was limited to human health settings.

The Pan-Canadian Public Health Network (PHN) represents Canada's national public health infrastructure to address such public health concerns. In 2014/2015, the PHN began identifying components of a pan-Canadian public health framework on AMR, focusing its attention on the key elements of stewardship pertaining to AMU in human health. The Communicable and Infectious Disease Steering Committee (CIDSC) Task Group on Antimicrobial Use Stewardship was mandated by the CIDSC under PHN to identify core components of a pan-Canadian stewardship approach, identify key challenges and gaps and recommend ways to promote stewardship across jurisdictions.

The objective of this article is to summarize the CIDSC Task Group Report on Antimicrobial Use Stewardship (9), which identifies the core components of antimicrobial stewardship programs and best practices in human health settings in Canada, highlights the challenges and gaps and presents a series of recommendations to advance antimicrobial stewardship in Canada.

\section{Methods}

The Antimicrobial Use Stewardship Task Group was composed of infectious disease experts, family and other clinical physicians, epidemiologists, microbiologists and public health experts. Search strategies were developed to identify scientific literature, grey literature and relevant websites on antimicrobial stewardship and were supplemented by additional information provided by members. Material was reviewed, and based on this evidence, expert opinion and consensus-building, the Task Group identified core components, best practices, key challenges and gaps and developed recommendations to advance stewardship in Canada.

\section{Results}

The search strategies resulted in over 400 articles which were reviewed and summarized for discussion by the Task Group. For the purposes of the Report, antimicrobial stewardship was defined as "coordinated interventions designed to promote, improve, monitor and evaluate the judicious use of antimicrobials in order to preserve their future effectiveness and promote and protect human health" $(9,10)$.

\section{Core components}

Promising stewardship programs suggest that strong interdisciplinary public health action and political engagement can lead to a measurable decrease in AMR and improved optimal AMU in health care settings. While more research is clearly needed to validate this and related findings in community settings, four core components of promising antimicrobial stewardship programs and initiatives emerged: leadership, interventions, monitoring and evaluation and research (Table 1).
Table 1: Description of the four core components of antimicrobial stewardship

\begin{tabular}{|l|l|}
\hline \multicolumn{1}{|c|}{$\begin{array}{c}\text { Core } \\
\text { component }\end{array}$} & \multicolumn{1}{c|}{ Description } \\
\hline Leadership & $\begin{array}{l}\text { Successful stewardship undertakings are grounded } \\
\text { in accountability, appropriate and sustained } \\
\text { resources and expertise, adequate support and } \\
\text { training and involve specialists in an interdisciplinary } \\
\text { manner. }\end{array}$ \\
\hline Interventions & $\begin{array}{l}\text { Effective stewardship interventions are } \\
\text { multipronged and comprehensive. They consist of } \\
\text { awareness, education and guidance. Furthermore, } \\
\text { they include various tools such as diagnostic tools, } \\
\text { providing evidence-based timely information and } \\
\text { engaging multiple target groups for maximum } \\
\text { effect. }\end{array}$ \\
\hline $\begin{array}{l}\text { Monitoring and } \\
\text { evaluation }\end{array}$ & $\begin{array}{l}\text { To establish the appropriate use of antimicrobials, } \\
\text { the literature consistently identifies the critical role } \\
\text { of benchmarks, audit and evaluation systems. }\end{array}$ \\
\hline Future research & $\begin{array}{l}\text { Includes knowledge creation, translation and } \\
\text { mobilization. Expertise from across research } \\
\text { disciplines must be leveraged in order to address } \\
\text { information gaps and ensure that evidence is } \\
\text { available and applied for greatest impact. }\end{array}$ \\
\hline
\end{tabular}

\section{Initiatives and best practices}

The Task Group identified successful stewardship programs that had been evaluated both within Canada and from other countries. The Canadian initiatives are summarized in Table 2. After reviewing these programs, the Task Group concluded that strong interdisciplinary public health action and political engagement can lead to a measurable decrease in AMR and improved optimal AMU in health care settings.

Table 2: Examples of best practices for antimicrobial stewardship in Canada'

\begin{tabular}{|c|c|c|}
\hline $\begin{array}{l}\text { Level of } \\
\text { intervention } \\
\text { and name }\end{array}$ & Program description & Outcome \\
\hline $\begin{array}{l}\text { Alberta } \\
\text { and British } \\
\text { Columbia } \\
\text { Do Bugs } \\
\text { Need Drugs? } \\
\text { (Initiated } \\
\text { in Grande } \\
\text { Prairie, } \\
\text { Alberta) (7) }\end{array}$ & $\begin{array}{l}\text { The program has a } \\
\text { dual focus: to provide } \\
\text { educational resources } \\
\text { to physicians, nurses } \\
\text { and pharmacists in } \\
\text { community hospitals } \\
\text { and long-term } \\
\text { care facilities; and } \\
\text { to provide public } \\
\text { education on AMR } \\
\text { risk and AMU to the } \\
\text { general public. }\end{array}$ & $\begin{array}{l}\text { A multimedia approach } \\
\text { using print materials, } \\
\text { advertising campaigns } \\
\text { and continuing education } \\
\text { and awareness for all ages } \\
\text { and a variety of health } \\
\text { professionals results in a } \\
\text { positive reach to many } \\
\text { target audiences. }\end{array}$ \\
\hline $\begin{array}{l}\text { Quebec } \\
\text { Multipronged } \\
\text { educational } \\
\text { strategy on } \\
\text { antibiotic } \\
\text { prescribing }\end{array}$ & $\begin{array}{l}\text { Guidelines were } \\
\text { disseminated using a } \\
\text { multidisciplinary and } \\
\text { mostly web-based } \\
\text { strategy, including } \\
\text { having downloadable } \\
\text { versions on a dedicated } \\
\text { website and promotion } \\
\text { by professionals } \\
\text { and experts during } \\
\text { educational events. }\end{array}$ & $\begin{array}{l}\text { Concise, user-friendly } \\
\text { science-based guidelines } \\
\text { prepared by credible } \\
\text { organizations, endorsed by } \\
\text { professional organizations } \\
\text { and actively promoted } \\
\text { have a significant impact } \\
\text { on reducing inappropriate } \\
\text { antimicrobial prescribing } \\
\text { practices in the community. }\end{array}$ \\
\hline
\end{tabular}


Table 2 continued

\begin{tabular}{|c|c|c|}
\hline $\begin{array}{l}\text { Level of } \\
\text { intervention } \\
\text { and name }\end{array}$ & Program description & Outcome \\
\hline $\begin{array}{l}\text { Ontario } \\
\text { Treating } \\
\text { respiratory } \\
\text { infections } \\
\text { in the } \\
\text { community }\end{array}$ & $\begin{array}{l}\text { A community-wide, } \\
\text { multidisciplinary } \\
\text { educational strategy } \\
\text { was used in Ontario } \\
\text { with the objectives of } \\
\text { enhancing adoption of } \\
\text { clinical guidelines and } \\
\text { improving AMU. }\end{array}$ & $\begin{array}{l}\text { Elements of success were } \\
\text { the development of user- } \\
\text { friendly and credible } \\
\text { materials, education of } \\
\text { the public, pharmacists } \\
\text { and clinicians and support } \\
\text { given to motivated local } \\
\text { health professionals in } \\
\text { coordinating educational } \\
\text { elements. }\end{array}$ \\
\hline $\begin{array}{l}\text { Ontario } \\
\text { Reducing C. } \\
\text { difficile in } \\
\text { Intensive Care } \\
\text { Units (Initiated } \\
\text { in Mount } \\
\text { Sinai Hospital, } \\
\text { Toronto, ON) }\end{array}$ & $\begin{array}{l}\text { The main intervention } \\
\text { techniques were the } \\
\text { use of an infectious } \\
\text { disease physician or } \\
\text { pharmacist leader, the } \\
\text { distribution of relevant } \\
\text { in-hospital educational } \\
\text { materials to health } \\
\text { care professionals, } \\
\text { then prospective audit } \\
\text { and feedback in the } \\
\text { Intensive Care Units. }\end{array}$ & $\begin{array}{l}\text { Key success factors } \\
\text { were appropriate human } \\
\text { resources for effective } \\
\text { leadership, decision } \\
\text { support, prospective } \\
\text { audit and feedback, } \\
\text { as well as knowledge } \\
\text { exchange via peer-to-peer } \\
\text { communication. }\end{array}$ \\
\hline
\end{tabular}

\section{Key challenges and knowledge gaps}

After identifying the core components of effective stewardship and reviewing successful stewardship programs and initiatives, important challenges and knowledge gaps emerged in the Task Group discussion (Table 3). For example, the success and sustainability of stewardship undertakings require appropriate and sustained resourcing and expertise (something which may not always be possible in a given setting or jurisdiction) and gaps exist concerning treatment guidance, its benefits, how to implement it, as well as ensuring accessibility, standardization and consistency of use among professionals.

\section{Table 3: Current challenges and gaps in antimicrobial} stewardship

\section{Challenges}

Appropriate resourcing: The success and sustainability of stewardship undertakings requires appropriate and sustained resourcing and, in particular, appropriate expertise (something which may not always be possible in a given setting or jurisdiction).

Access and consistency of guidelines: Canadian physicians have reported difficulty locating relevant resources regarding AMR in general and regarding testing protocols. Different guideline documents are available for different prescribing professionals.

Follow up of effectiveness of treatments/programs: Integration of test-of-cure (re-culturing at the site of infection to determine if infection is still present) into guidance documents. The lack of standardized indicators makes it difficult to determine the effectiveness of the programs/campaigns.

\section{Gaps}

Lack of training: Educational and training initiatives regarding stewardship targeted at all prescribing professionals are needed.

Identifying when not to prescribe: More research is required to determine whether producing prescriber guidance on when not to prescribe antibiotics would be beneficial and how to implement it.

Need for rapid diagnosis: Rapid point-of-care diagnostic tools that distinguish bacterial from viral infections and identify and characterize resistant bacteria are needed to guide appropriate use of antimicrobials.

\section{Recommendations}

Based on the core components, best practices, current challenges and gaps, the Task Group developed recommendations to advance antimicrobial stewardship in Canada (Table 4). Implementation of the Report recommendations will need to take into account current developments in the policy and program research domains.

\section{Table 4: Recommendations to CIDSC for core components of antimicrobial stewardship practices in Canada}

\begin{tabular}{|c|c|}
\hline $\begin{array}{c}\text { Core } \\
\text { component }\end{array}$ & Recommendation(s) to CIDSC \\
\hline Leadership & $\begin{array}{l}\text { A National infrastructure (e.g., governance, network, } \\
\text { resources, etc.) be put in place to support provinces and } \\
\text { territories in the development of stewardship programs in } \\
\text { both health care and community settings. }\end{array}$ \\
\hline \multirow{3}{*}{ Interventions } & $\begin{array}{l}\text { Best practices, benchmarks or standards for education and } \\
\text { awareness activities that require the engagement of multiple } \\
\text { prescribers, and have a dual focus on prescribers and users. }\end{array}$ \\
\hline & $\begin{array}{l}\text { The consistency and availability of guidance; information, } \\
\text { tools and training for prescribing professionals and users be } \\
\text { comprehensive, available and consistent to support local } \\
\text { prescribers. }\end{array}$ \\
\hline & $\begin{array}{l}\text { Universities, colleges and technical schools that train future } \\
\text { prescribers incorporate mandatory stewardship education and } \\
\text { continuing education curricula for prescribing professionals. }\end{array}$ \\
\hline \multirow[b]{2}{*}{$\begin{array}{l}\text { Monitoring and } \\
\text { evaluation }\end{array}$} & $\begin{array}{l}\text { Evidence-based audit and feedback tools be developed to } \\
\text { support prescribers and that guidance for prescribers be } \\
\text { evaluated, adapted and implemented at regional and local } \\
\text { levels }\end{array}$ \\
\hline & $\begin{array}{l}\text { Benchmarks be established for optimal antimicrobial use by } \\
\text { type of infection and populations at greatest risk for infection } \\
\text { and that jurisdictions work together to establish performance } \\
\text { targets for stewardship in hospital and other settings; and that } \\
\text { timely evaluations of stewardship programs be conducted and } \\
\text { publicly accessible. }\end{array}$ \\
\hline \multirow{2}{*}{ Future research } & $\begin{array}{l}\text { Further evidence about prescribing behaviours of professionals } \\
\text { be collected, shared and mobilized so that specific } \\
\text { interventions for these professions can be implemented. }\end{array}$ \\
\hline & $\begin{array}{l}\text { Changes be made to health care practitioners' practice } \\
\text { regulations and that further evidence will need to be gathered } \\
\text { to guide and support such changes. }\end{array}$ \\
\hline
\end{tabular}

The Task Group also identified two additional considerations. First, that patient safety, avoidance of unwanted side effects and effective infection prevention and control practices are all important factors further contributing to antimicrobial stewardship initiatives. Second, the Task Group suggested that the evaluation of stewardship programs and initiatives be promoted with granting agencies and be considered for inclusion as part of AMU/AMR priorities for funding.

\section{Conclusion}

The Task Group identified that leadership, appropriate interventions, monitoring and evaluation, the need for more knowledge about effective stewardship-and the evidence-base that will advance it-are key components of promising antimicrobial stewardship programs and initiatives. There are a number of key challenges and existing knowledge gaps that can be addressed by the Task Group recommendations that have 
been put forward. These are currently under consideration by governments and health care experts.

Better managing antimicrobial use is a shared responsibility among multiple stakeholders including public health and health care professionals, health care organizations, local, provincial, territorial, national governments, the research community and others who provide and use antimicrobials and who care for the people who use them. The development, promotion and implementation of initiatives to promote optimal use of antimicrobials across Canada will require collaboration among all of these stakeholders, helping to create synergies that will effectively combat AMR.

\section{Acknowledgements}

The authors gratefully acknowledge the 2015 CIDSC Task Group on AMU Stewardship members for their contributions and expert advice:

Dean Blue (Co-Chair), Office of the Chief Medical Officer of Health, Alberta; John Conly, Alberta Health Services and University of Calgary; Gary Garber, Public Health Ontario; Greg German, Health Prince Edward Island; Melissa Helferty, Ministry of Health and Long Term Care, Ontario; David Patrick, British Columbia Centre for Disease Control; Jeff Powis, Michael Garron Hospital, Toronto ON; Richard Rusk, Manitoba Health, Seniors and Active Living; Nadine Sicard, ministère de la Santé et des Services sociaux, QC

Public Health Agency of Canada: Kanchana Amaratunga, Jacqueline Arthur (Secretariat), Christine Cryan (Secretariat), Monika Dankova, Rita Finley, Katie Freer (until August 2015), Robert Gervais, Edward Gertler, Leanne Maidment (Co-Chair), Stephanie Mehta (Secretariat), Valerie Sarazin (Secretariat - until July 2015), Shari Silber (Secretariat), Christine N. Soon, Deepika Sriram (Secretariat - until October 2015), Geneviève Tremblay (until August 2015)

\section{Conflict of interest}

None. Jacqueline Arthur is one of the Guest Editors for this issue and recused herself from taking editorial decisions on this manuscript. Editorial decisions were made by the Editor-in-Chief, Dr. Patricia Huston and the other Guest Editor Dr. Kanchana Amaratunga.

\section{Funding}

This work was supported by the Public Health Agency of Canada.

\section{References}

1. Wang E, Einarson T, Kellner J, Conly J. Antibiotic prescribing patterns for respiratory tract infections in preschool children in Saskatchewan: Evidence for overprescribing for viral syndromes. Clin Infect Dis. 1999;29:155-60.

2. Nicolle LE. Infection prevention issues in long-term care. Curr Opin Infect Dis. 2014;27(4):363-69.

3. Silver SA, Baillie L, Simor AE. Positive urine cultures: A major cause of inappropriate antimicrobial use in hospitals? Can J Infect Dis Med Microbiol. 2009;20(4):107-11.

4. Leis JA, Rebick GW, Daneman N, Wayne GL, Poutanen SM, Lo P, Larocque M, Shojania KG, McGeer A. Reducing antimicrobial therapy for asymptomatic bacteriuria among noncatheterized inpatients: A proof-of-concept study. Clin Infec Dis. 2014;58(7)980-3.

5. Moody J, Cosgrove SE, Olmsted RN, Septimus E, Aureden K, Oriola S. et al, Antimicrobial stewardship: A collaborative partnership between infection preventionists and health care epidemiologists. Am J Infect Control. 2012;40:94-5.

6. McKay RM, Vrbova L, Fuertes E, Chong M, David S, Dreher $\mathrm{K}$ et al. Evaluation of the Do Bugs Need Drugs Program in British Columbia: Can we curb antibiotic prescribing? Can J Infect Dis Med Microbiol. 2011;22(1):19-24.

7. Carson M, Patrick DM. Do Bugs Need Drugs? A community education program for the wise use of antibiotics. Can Comm Dis Rep. 2015;41(Suppl 4):5-9. Available from: http://www.phac-aspc.gc.ca/publicat/ccdr-rmtc/15vol41/drrm41s-4/overview-apercu_01-eng.php.

8. British Columbia Centre for Disease Control [Internet]. Do Bugs Need Drugs? Annual evaluation report 2013/14. Vancouver BC: BCCDC; 2014. Available from: http://www. bccdc.ca/NR/rdonlyres/2CE3760F-4A41-4F7E-89DC-2F8CD 39A6F92/0/201314DBNDAnnualEvaluationReport_FINAL_ amended.pdf.

9. Pan-Canadian Public Health Network, The Communicable and Infectious Disease Steering Committee Task Group on Antimicrobial Use Stewardship [Internet]. Report to CIDSC: Antimicrobial Stewardship: Final Report to the Public Health Network Council. Ottawa ON: PHAC; Apr 2016. Available from: https://www.phn-rsp.ca/en/reports-publications/ antimicrobial-stewardship.html.

10. National Institute for Health and Care Excellence (NICE) [Internet]. UK Committee Task Group on Antimicrobial Use Stewardship. Antimicrobial Stewardship: Systems and Processes for Effective Antimicrobial Medicine Use. [updated: 2015 Aug 18; cited 2016 Oct 10]. Available from: https://www.nice.org.uk/guidance/ng15. 